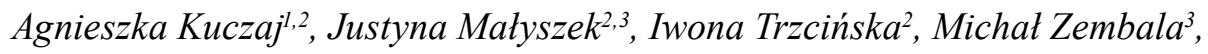

Piotr Przybytowski $i^{2,4}$

\title{
COVID-19 MORBIDITY IN PATIENTS AFTER ORTHOTOPIC HEART TRANSPLANTATION - SINGLE CENTER CLINICAL OBSERVATION
}

\section{ZACHOROWALNOŚĆ NA COVID-19 WŚRÓD CHORYCH PO ORTOTOPOWYM PRZESZCZEPIENIU SERCA - OBSERWACJA JEDNOOŚRODKOWA}

\author{
${ }^{1}$ Medical University of Silesia, Poland. Department of Cardiac, Vascular and Endovascular Surgery and \\ Transplantology. Faculty of Medical Sciences in Zabrze \\ Śląski Uniwersytet Medyczny. Wydział Nauk Medycznych w Zabrzu. Katedra i Oddział Kliniczny \\ Kardiochirurgii, Transplantologii, Chirurgii Naczyniowej i Endowaskularnej \\ ${ }^{2}$ Silesian Center for Heart Diseases in Zabrze, Poland. Heart transplantation outpatient clinic \\ Śląskie Centrum Chorób Serca w Zabrzu, Zabrze, Polska. Poradnia Transplantacyjna \\ ${ }^{3}$ Cardiac surgery ward. Silesian Center for Heart Diseases in Zabrze, Poland \\ Śląskie Centrum Chorób Serca w Zabrzu, Zabrze, Polska. Oddział Kardiochirurgii \\ ${ }^{4}$ Jagiellonian University Krakow, Poland. Collegium Medicum \\ Uniwersytet Jagielloński, Kraków, Polska. Collegium Medicum
}

\begin{abstract}
INTRODUCTION. The study is a prospective clinical observation of patients after orthotopic heart transplantation in a large academic medical center in relation to COVID-19 morbidity. The study population was comprised of 552 patients. All patients were consulted and advised by telephone as regards the prophylaxis of SARS-CoV-2 infection. Hospital and outpatient follow-ups were limited to the minimum. Preventive modification of immunosuppression was not recommended in relation to the pandemic. Three patients with multiple comorbidities (a woman aged 60, a man aged 59, and another man aged 83; 2.25 years, 5.5 years, and 7.5 years after heart transplantation, respectively) and one patient with concomitant arterial hypertension (a woman aged 48, 5.5 years after heart transplantation) presented with a symptomatic COVID-19 infection. Three of the patients were on tacrolimus immunosuppression, and both female patients were additionally on therapy with mycophenolate mofetil, which was discontinued following the diagnosis of infection. One male patient received combined therapy of cyclosporine A and mycophenolate mofetil. The 60-year-old woman presented with gastrointestinal manifestations of the COVID-19 infection which were of moderate severity. The recovery was achieved. The 59-year-old man presented with myocardial infarction, exacerbated renal insufficiency that required hemodialysis and cardiorespiratory failure complicated by bacterial sepsis. As a result, the patient died. The 83-year-old male patient reporting fever, myalgia, fatigue, cough and dyspnea was admitted to hospital and deceased due to septic shock two days after admission. The 48-year old woman who presented with mild symptoms of the upper respiratory tract infection recovered after two weeks. Symptomatic treatment was used in all the patients. Another male patient (aged 45 years, 8 years after orthotopic heart transplant with no significant comorbidities) was an asymptomatic carrier of SARS-CoV-2 and remained under hospital care.
\end{abstract}

Conclusions: Of 552 patients after orthotopic heart transplantation, two SARS-CoV-2-related deaths were reported.

Key words: COVID-19 infection, SARS-CoV-2, orthotopic heart transplantation, immunosuppression

C National Institute of Public Health - National Institute of Hygiene / Narodowy Instytut Zdrowia Publicznego - Państwowy Zakład Higieny 


\section{STRESZCZENIE}

Praca jest prospektywną obserwacją kliniczną zachorowalności na COVID-19 wśród chorych po ortotopowym przeszczepieniu serca pozostających pod opieką ambulatoryjną dużego ośrodka akademickiego. Badana populacja obejmowała 552 pacjentów po ortotopowym przeszczepieniu serca. Wszystkim chorym udzielono teleporad odnośnie profilaktyki infekcji SARS-CoV2. Wizyty szpitalne i kontrole w poradni zostały ograniczone do niezbędnego minimum. Nie zalecano prewencyjnej modyfikacji farmakoterapii w związku z pandemią. U trzech chorych z licznymi chorobami współistniejącymi (kobieta lat 60, mężczyzna lat 59 oraz mężczyzna lat 83 , odpowiednio 2,25, 5,5 i 7,5 lat po transplantacji) oraz u jednego pacjenta ze współistniejącym nadciśnieniem tętniczym (kobieta lat 48, 5,5 lat po przeszczepieniu serca) wystąpiła objawowa infekcja. Trzech chorych otrzymywało immunosupresję złożoną takrolimusu w monoterapii, pacjentki otrzymywały dodatkowo mykofenolan mofetylu, który został czasowo wstrzymany po rozpoznaniu infekcji. Jeden chory otrzymywał terapię złożoną z cyklosporyny A i mykofenolanu mofetylu. U 60-letniej kobiety wstąpiły objawy ze strony układu pokarmowego o umiarkowanym nasileniu. Uzyskano wyzdrowienie. 59-letni mężczyzna został przyjęty z objawami zawału serca, zaostrzeniem przewlekłej choroby nerek, wymagającej dializoterapii oraz niewydolności krążeniowo-oddechowej powikłanej przez posocznicę bakteryjną; chory zmarł. 83-letni chory zgłaszający gorączkę, bóle mięśniowe, kaszel i duszność został przyjęty do szpitala i zmarł w objawach wstrząsu septycznego dwa dni po przyjęciu. 48-letnia chora prezentowała łagodne objawy ze strony górnych dróg oddechowych, wyzdrowiała po 2 tygodniach. U wszystkich chorych stosowano leczenie objawowe. U jednego chorego (45 lat, 8 lat po transplantacji serca, bez istotnych chorób współistniejących) stwierdzono bezobjawowe nosicielstwo SARS$\mathrm{CoV}-2$, z obawy przed nagłym pogorszeniem pozostawał pod opieką szpitalną.

Wnioski: Spośród 552 chorych po ortotopowym przeszczepieniu serca odnotowano dwa zgony związane z SARS-CoV-2.

Słowa kluczowe: infekcja COVID-19, SARS-CoV-2, ortotopowe przeszczepienie serca

\section{INTRODUCTION}

In the face of the COVID-19 pandemic, there were concerns that the disease could have a severe course in patients after solid organ transplantation. Preliminary reports suggested very high mortality in patients on immunosuppressive treatment (1-4). In other case studies, (5) it was found that mortality was slightly higher in patients after organ transplantation compared to the general population despite immunosuppression. Some studies even suggested a protective role of immunosuppression against the "cytokine storm" reported in the third phase of COVID-19 (6). We present single center observation comprising large cohort of heart transplant patients.

\section{METHODS}

The study comprises patients prospectively enrolled from March until mid-October 2020 remaining the under supervision of the outpatient transplantation clinic. According to the guidelines of the International Society for Heart and Lung Transplantation (ISHLT) [7], hospitalizations and outpatient visits were reduced to the minimum. Staying at home and avoiding social contact were advised. We did not recommend modification of immunosuppressive treatment as a prophylactic measure. Additionally, before the scheduled visit, the infection-related telephone survey
WSTĘP

W obliczu pandemii COVID-19 pojawiły się obawy związane z potencjalnie ciężkim przebiegiem w grupie chorych po transplantacji narządowej. Wczesne doniesienia sugerowały bardzo wysoką śmiertelność wśród chorych otrzymujących leczenie immunosupresyjne (1-4). W części analiz (5) wykazano, że śmiertelność wśród biorców organów w porównaniu do populacji ogólnej jest jedynie nieznacznie wyższa, mimo stosowanego leczenia immunosupresyjnego. Niektóre badania wykazywały wręcz ochronną role immunosupresji przeciw "burzy cytokinowej" stanowiącej trzecia fazę COVID-19 (6).

Poniżej przedstawiamy jednoośrodkową obserwację chorych po transplantacji serca pod względem infekcji SARS-CoV-2.

\section{METODYKA}

Badanie obejmuje chorych prospektywnie włączonych od marca do połowy października 2020, pozostających pod opieką poradni transplantacyjnej. Zgodnie $\mathrm{z}$ wytycznymi Międzynarodowego Towarzystwa Przeszczepiania Serca i Płuc (International Society for Heart and Lung Transplantation, ISHLT) (7), hospitalizacje oraz porady stacjonarne zostały ograniczone do nieodzownego minimum. Zalecano pozostawanie w domu oraz unikanie kontaktów społecznych. Nie re- 
was conducted. Active search for patients staying under the epidemiological surveillance due to the SARSCoV-2 infection was performed weekly (via a national insurance electronic system). Routine visits were changed into telephone consultations, which were twice more frequent than routine visits. During the working time of the outpatient clinic, a transplantation nurse and doctor were available on phone for consultation. The observed infections were noted between June and midOctober 2020.

Statistical analysis: due to small number of clinical cases no advanced statistical methods were used (number of cases, total number of patients).

\section{RESULTS AND DISCUSSION}

Of 552 patients after orthotopic heart transplantation (OHT) who lived in Poland and who were under the supervision of the outpatient transplantation clinic, only four patients presented with the symptoms of COVID-19 infection and one patient was an asymptomatic carrier who remained under hospital supervision.

We present 5 cases of heart transplant patients with COVID-19 infection.

\section{Case one}

A 60-year old female patient, 2.25 years after OHT, with arterial hypertension, chronic kidney disease, hyperuricemia and hypothyroidism, complained of severe diarrhea and a low-grade fever. The patient was still on chronic immunosuppressive therapy, including tacrolimus and mycophenolate mofetil. The patient was also on atorvastatin $(10 \mathrm{mg})$, allopurinol (200 $\mathrm{mg}$ ), levothyroxine (25ug) and acetylsalicylic acid (75 $\mathrm{mg}$ ). Her family history was negative for SARS-CoV-2 infection. The patient was a resident of the Upper Silesia region where the epidemic intensity was high and the household member was a healthcare worker. Trimethoprim/sulfamethoxazole and ciprofloxacin were initially administered. However, due to the lack of improvement and persistent fever $\left(38^{\circ} \mathrm{C}\right)$, the patient was referred to hospital. The first SARS-CoV-2 realtime reverse transcription polymerase chain reaction (RT-PCR) of a nasopharyngeal swab was negative. Another assessment performed 4 days later due to persistent clinical symptoms was positive. Laboratory findings showed no significant leucopenia: white blood count (WBC) $4.41 \times 10^{\wedge} 3 / \mu 1$, lymphocytes 1.24 x $10^{\wedge} 3 / \mu 1$, neutrophils $2.3 \times 10^{\wedge} 3 / \mu 1$, c-reactive protein (CRP) $42.5 \mathrm{mg} / \mathrm{l}$, d-dimer $1534 \mu \mathrm{g} / \mathrm{ml}$, GFR by the MDRD equation $32 \mathrm{ml} / \mathrm{min} / 1.73 \mathrm{~m}^{2}$. Another followup assessment 14 days later confirmed the presence of the virus. A negative result was obtained 22 days after the first positive result, which was also confirmed later. The baseline chest computed tomography (chest-CT) komendowano modyfikacji farmakoterapii immunosupresyjnej, jako środka zapobiegawczego. Dodatkowo, przed zaplanowaną wizytą przeprowadzano ankietę telefoniczną odnoście ryzyka infekcji. Co tydzień aktywnie przeszukiwano bazę chorych pod względem pozostawania w kwarantannie z powodu SARS-CoV-2 (za pośrednictwem systemu ubezpieczenia zdrowotnego).

Rutynowe wizyty były zastąpione konsultacjami telefonicznymi, które wykonywano dwukrotnie częściej niż wizyty rutynowe. Dodatkowo, w godzinach pracy poradni transplantacyjnej pielęgniarka transplantacyjna oraz lekarz pozostawali do dyspozycji celem konsultacji telefonicznych. Zaobserwowane infekcje wystąpiły pomiędzy czerwcem i połową października 2020r.

Analiza statystyczna: z powodu małej liczby zaobserwowanych przypadków klinicznych nie stosowano zaawansowanych metod statystycznych. Posługiwano się liczba chorych.

\section{WYNIKI I DYSKUSJA}

Spośród 552 chorych po ortotopowym przeszczepieniu serca (orthotopic heart transplantation, OHT) pozostających pod opieką poradni transplantacyjnej, jedynie u czterech wystąpiła objawowa infekcja SARS-CoV-2, $\mathrm{u}$ jednego chorego odnotowano infekcję bezobjawową, pozostawał on pod obserwacją szpitalną.

Poniżej prezentujemy przebieg kliniczny 5 zainfekowanych chorych.

\section{Przypadek pierwszy}

U 60-letniej kobiety 2,25 roku po OHT, z nadciśnieniem tętniczym, przewlekłą chorobą nerek, hiperurykemią, niedoczynnością tarczycy wystąpiła nasilona biegunka oraz stany podgorączkowe. Pacjentka otrzymywała przewlekle leczenie immunosupresyjne złożone z takrolimusu oraz mykofenolanu mofetylu. Chora pozostawała także na terapii atorwastatyną $(10 \mathrm{mg})$, allopurinolem $(200 \mathrm{mg})$, i lewotyroksyną (25ug) oraz kwasem acetylosalicylowym. W wywiadzie nie odnotowano infekcji SARS-CoV-2 wśród członków rodziny, natomiast jedna z zamieszkujących wspólne gospodarstwo domowe osób była pracownikiem służby zdrowia. Pacjentka przebywała na obszarze Górnego Śląska, gdzie odnotowywano wówczas znaczne nasilenie epidemii.

Początkowo zastosowano trimethoprim $\mathrm{z}$ sulfametoksazolem oraz ciprofloksacynę. Z powodu braku poprawy klinicznej i utrzymującej się gorączki $\left(38^{\circ} \mathrm{C}\right)$ chorą skierowano do szpitala. Pierwszy wynik oznaczenia wymazu z nosa i gardła w kierunku SARS-CoV-2 metodą RT-PCR (real-time reverse transcription polymerase chain reaction) był ujemny. Kolejne oznaczenie wykonane 4 dni później z powodu utrzymujących się objawów klinicznych wykazało już wynik dodatni. 
reveled no inflammatory changes. Cough, dyspnea or desaturation were not reported either.

Due to the cytostatic effect on T cells, mycophenolate mofetil was temporarily discontinued. Allopurinol and atorvastatin were also discontinued. No antiviral or off-label treatment was used due to the potential interaction with immunosuppression. During the follow-up, gradual normalization of CRP was observed and diarrhea and fever resolved. Three weeks after recovery, endomyocardial biopsy revealed no significant
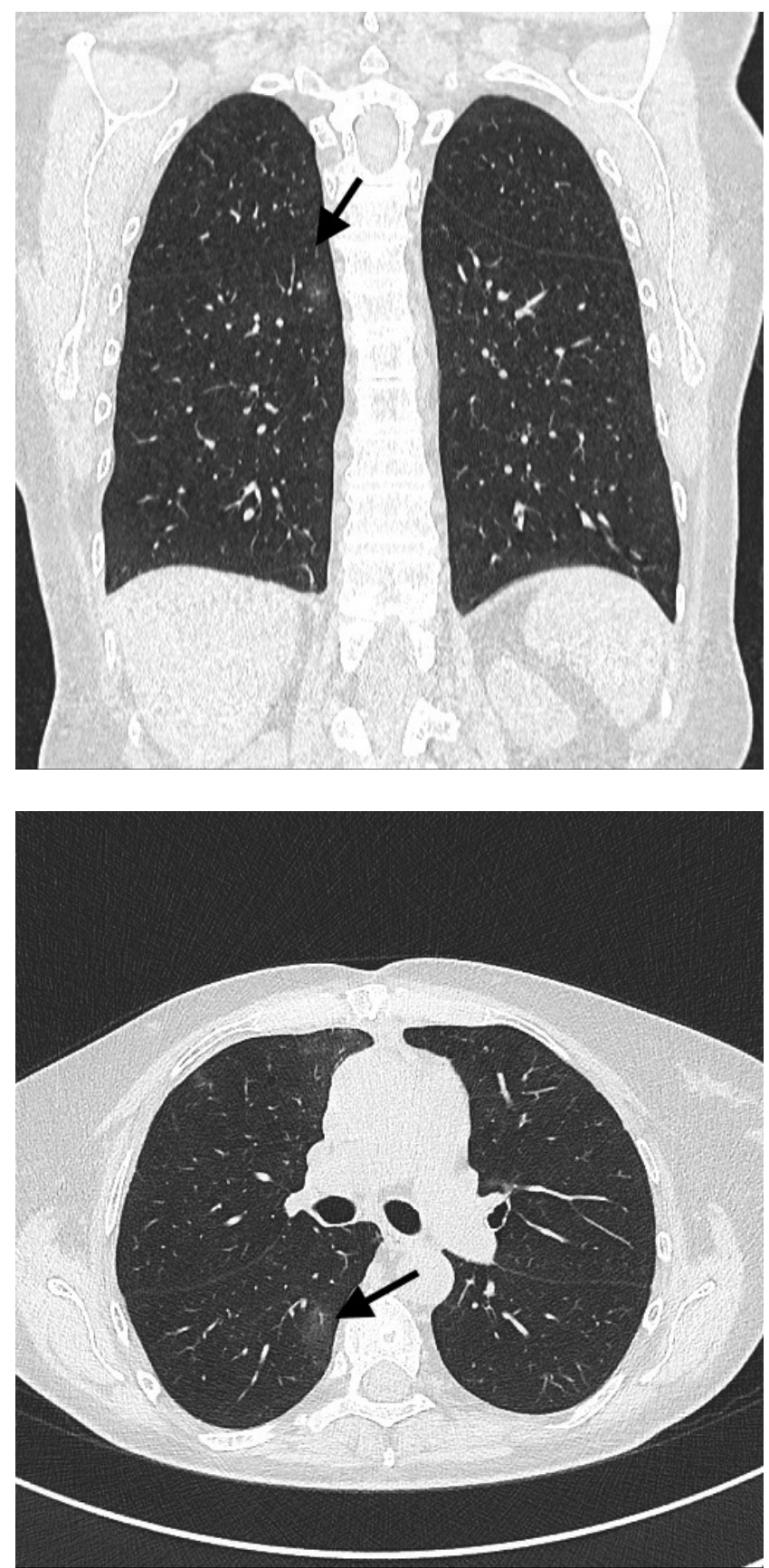

W badaniach laboratoryjnych nie odnotowano istotnej leukopeni (liczba krwinek białych $4.41 \times 10^{\wedge} 3 / \mu 1$, limfocyty $1.24 \times 10^{\wedge} 3 / \mu 1$, neutrofile $\left.2.3 \times 10^{\wedge} 3 / \mu \mathrm{l}\right)$. W pozostałych wynikach białko C-reaktywne (CRP) 42.5 $\mathrm{mg} / \mathrm{l}$, d-dimer $1534 \mu \mathrm{g} / \mathrm{ml}$, GFR ocenione na podstawie wzoru MDRD $32 \mathrm{ml} / \mathrm{min} / 1.73 \mathrm{~m}^{2}$.

W kolejnym oznaczeniu wirusa po 14 dniach potwierdzono utrzymywanie się jego obecności. Pierwszy wynik ujemny, potwierdzony w kolejnym oznaczeniem uzyskano po 22 dniach od pierwszego wyniku pozytywnego. W pierwszej, wykonanej kontrolnie tomografii komputerowej klatki piersiowej nie stwierdzano nieprawidłowości. Nie stwierdzano również objawów ze strony układu oddechowego (brak duszności, kaszlu, desaturacji).

Z powodu wpływu cytostatycznego na limfocyty $\mathrm{T}$, mykofenolan mofetylu był czasowo wstrzymany. Nie stosowano żadnego dodatkowego leczenia przeciwwirusowego lub eksperymentalnego $\mathrm{z}$ powodu obaw przed ewentualnymi interakcjami z leczeniem immunosupresyjnym. W dalszej ocenie obserwowano stopniową normalizację CRP, ustąpiły biegunka i stany podgorączkowe. Trzy tygodnie po wyzdrowieniu biopsja endomiokardialna nie wykazała istotnego odrzucania komórkowego (lb wg ISHLT). Wdrożono ponownie wcześniejsze leczenie immunosupresyjne (takrolimus o przedłużonym uwalnianiu wraz $\mathrm{z}$ mykofenolanem mofetylu). Ponownie włączono atorwastatynę oraz allopurinol. Sześć tygodni od pierwszej diagnozy wykona-

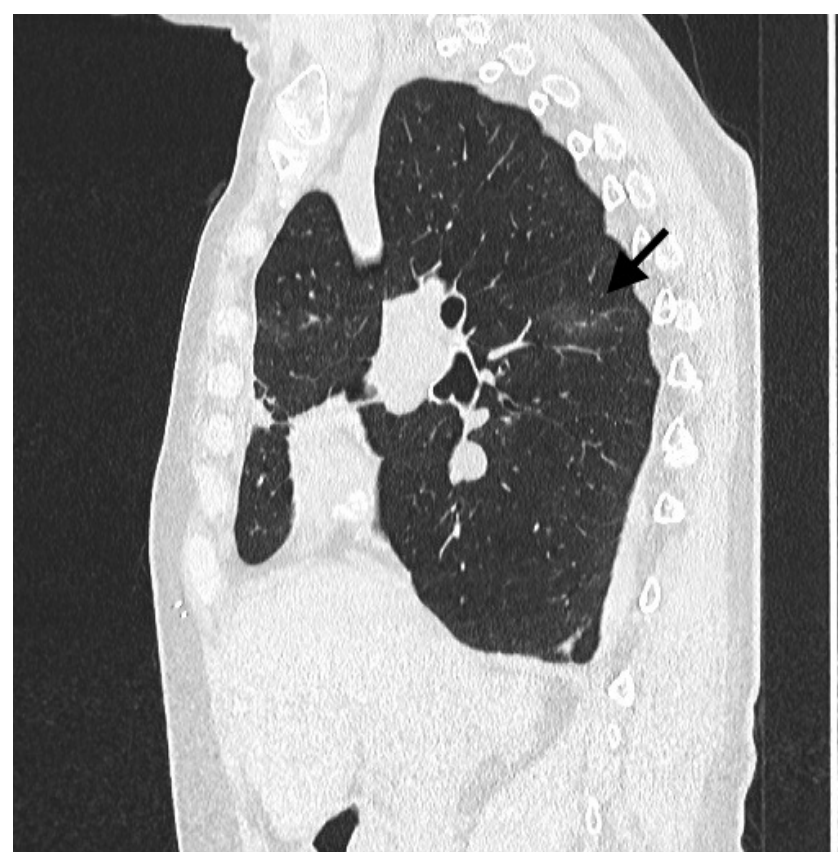

Fig 1. Chest CT showing small ground-glass foci in the right lung

Ryc. 1 Tomografia komputerowa klatki piesiowej uwidaczniająca ogniska mlecznej szyby w prawym płucu. 
cellular rejection (ISHLT grade 1B). We reintroduced immunosuppressive treatment (extended-release tacrolimus and mycophenolate mofetil). The patient was again given atorvastatin and allopurinol. Six weeks after the initial diagnosis, the follow-up chestCT revealed small ground-glass foci in the right lung (Fig. 1).

\section{Case two}

A 59-year-old male patient 5.5 years after heart transplantation complained of progressive dyspnea, cough and a low-grade fever. The patient had a history of multiple comorbidities (type 2 diabetes, hyperuricemia, stage 4 chronic kidney disease, post thrombotic syndrome of left lower limb, past tuberculosis prior to transplantation). Due to worsening of the clinical condition, the patient sought medical attention.

Previously normal graft function without regional contractility abnormalities had been observed. Due to chronic kidney disease, protocol coronary angiography was not performed to assess vasculopathy progression. The patient was given extended-release tacrolimus and additional pharmacotherapy consisted of atorvastatin (10 mg), acetylsalicylic acid (75mg), warfarin, insulin, and allopurinol (100 mg). no kontrolne TK klatki piersiowej, które wykazało drobne ogniska mlecznej szyby w prawym płucu (Ryc. 1).

\section{Przypadek drugi}

59-letni mężczyzna 5,5 roku po OHT zaczął się uskarżać na postępującą duszność, kaszel i stany podgorączkowe. Pacjent był obciążony wielochorobowością (cukrzyca typu 2, hiperurykemia, przewlekła choroba nerek w stadium 4, przebyta zakrzepica żylna lewej kończyny dolnej, przebyta przed transplantacją gruźlica). $Z$ powodu pogorszenia stanu zdrowia pacjent poszukiwał pomocy medycznej.

U chorego opisywano uprzednio prawidłową funkcję graftu, bez odcinkowych zaburzeń kurczliwości. Z powodu przewlekłej choroby nerek odstąpiono uprzednio od protokolarnych koronarografii wykonywanych w celu oceny progresji waskulopatii. Pacjent otrzymywał takrolimus $\mathrm{w}$ formie o przewlekłym uwalnianiu. Dodatkowa farmakoterapia obejmowała atorwastatyne (10mg), kwas acetylosalicylowy (75mg), warfarynę, insulinę i allopurinol (100mg).

Dodatkowo stosowano przewlekle następujące leki: lerkanidypinę (20mg), klonidynę 150ug trzy razy dziennie), doksazosynę (8mg, dwa razy dziennie) i furosemid.

W chwili przyjęcia do szpitala stwierdzono cechy obrzęku płuc z wysokimi wartościami ciśnienia tętni-

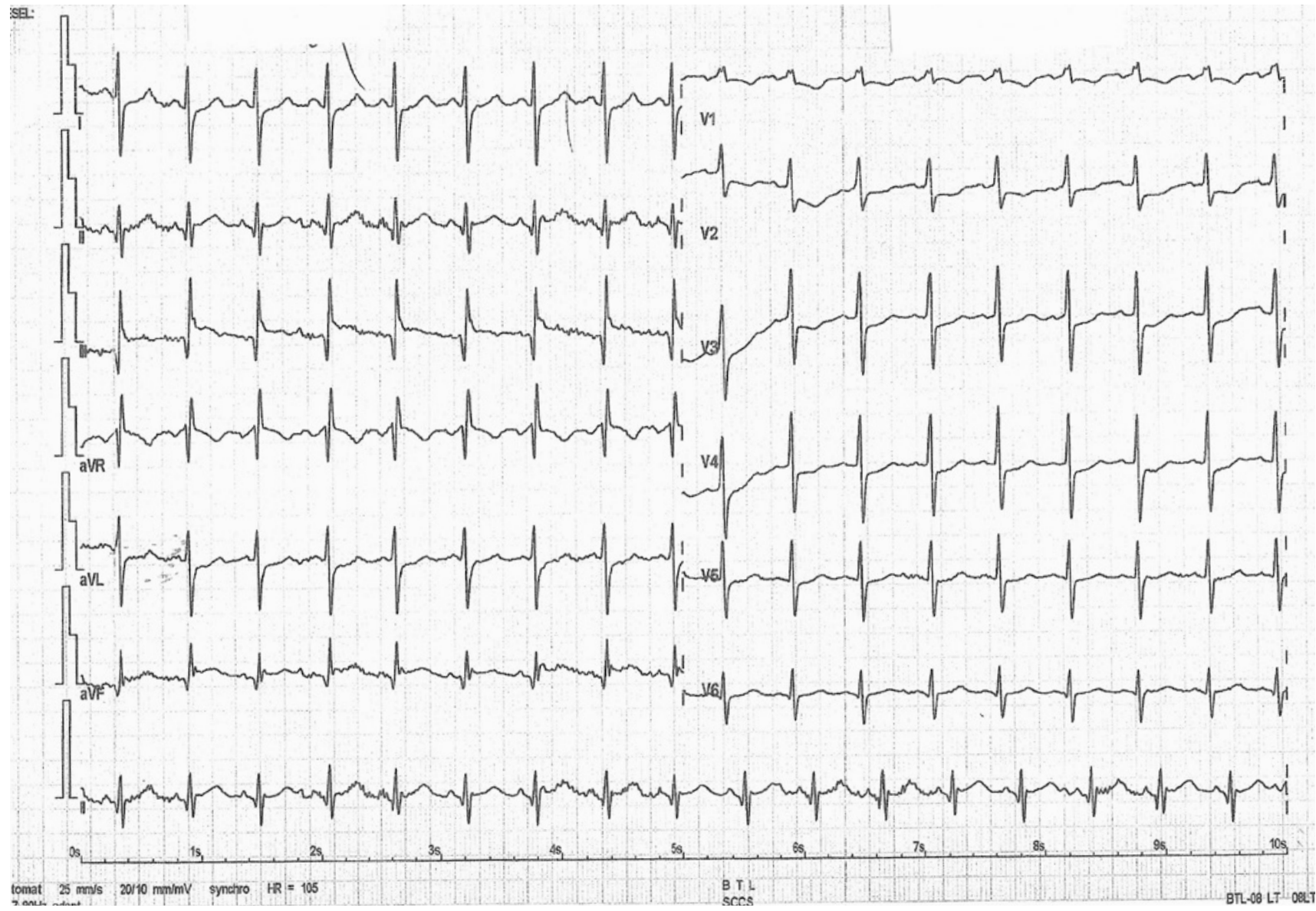

Fig. 2 ECG in a patient after heart transplant showing inferior and lateral wall myocardial infarction Ryc. 2 EKG u chorego po przeszczepieniu serca wykazujące cechy zawału ściany dolnej I bocznej. 
Additionally, the following antihypertensives were administered: lercanidipine $(20 \mathrm{mg})$, clonidine (150 ug; 3 times daily), doxazosin ( $8 \mathrm{mg}$; twice daily) and furosemide (40 mg).

At the time of hospital admission, signs and symptoms of pulmonary edema with concomitant high blood pressure $(180 / 110 \mathrm{mmHg})$ were observed. ECG showed inferior and lateral wall myocardial infarction.

Echocardiographic examination confirmed decreased left ventricular ejection fraction (LVEF $40 \%$ ), wall motion abnormalities (consistent with ECG findings) and a moderate mitral regurgitation. Laboratory findings showed elevated troponin ( $>4000 \mathrm{ng} / \mathrm{l})$ and d-dimer $(5200 \mu \mathrm{g} / \mathrm{l})$ levels, significantly elevated creatinine level $(304 \mu \mathrm{mol} / \mathrm{l})$, elevated CRP $(158 \mathrm{mg} / \mathrm{l})$ and procalcitonin $(1.35 \mathrm{ng} / \mathrm{ml})$. The results of the blood count were as follows: white blood count (WBC) $18.12 \times 10^{3} / \mu 1$, hemoglobin (HGB) $7.9 \mathrm{mmol} /$ $\mu \mathrm{l}$, hematocrit (HCT) $0.38 \%$ and platelet (PLT) count $236 \times 10^{3} / \mu 1$.

RT-PCR of a nasopharyngeal swab showed no SARSCoV-2 infection. However, IgG antibodies against the virus were present. Consistent clinical data (previous cough, fever, pandemic state in the region) suggested prior SARS-CoV-2 infection. Initially, standard czego krwi (180/110mmHg). EKG wykazało cechy zawału ściany dolnej i bocznej.

Badanie echokardiograficzne potwierdziło obniżoną frakcję wyrzutową lewej komory (left ventricular ejection fraction, LVEF) wynoszącą $40 \%$, odcinkowe zaburzenia kurczliwości zgodne z obrazem EKG, umiarkowaną niedomykalność zastawki mitralnej. W badaniach laboratoryjnych wykazano podwyższone markery martwicy mięśnia sercowego (troponina wysokoczuła $>4000 \mathrm{ng} / \mathrm{l})$, podwyższone wartości d-dimerów (5200 $\mu \mathrm{g} / \mathrm{l})$, istotnie podwyższoną kreatyninę $(304 \mu \mathrm{mol} / \mathrm{l})$, podwyższone CRP $(158 \mathrm{mg} / \mathrm{l})$ i prokalcytoninę $(1,35 \mathrm{ng} /$ $\mathrm{ml}$ ). Obraz morfologii krwi obwodowej przedstawiał się

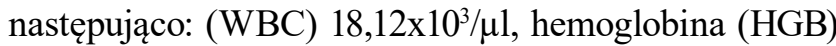
$7,9 \mathrm{mmol} / \mu \mathrm{l}$, hematokryt (HCT) $0,38 \%$, liczba płytek (PLT) $236 \times 10^{3} / \mu 1$.

W wykonanym RT-PCR wymazu z nosa i gardła nie potwierdziło obecności wirusa, jednak potwierdzono obecność przeciwciał przeciwwirusowych w klasie IgG.

Zgodne dane kliniczne (wcześniejszy kaszel, gorączka, stan epidemii w regionie, w którym przebywał chory) sugerowały wcześniejszą infekcję SARS-CoV-2. Początkowo, zastosowano typowe leczenie obrzęku płuc i zawału serca (dożylna nitrogliceryna, furosemid,

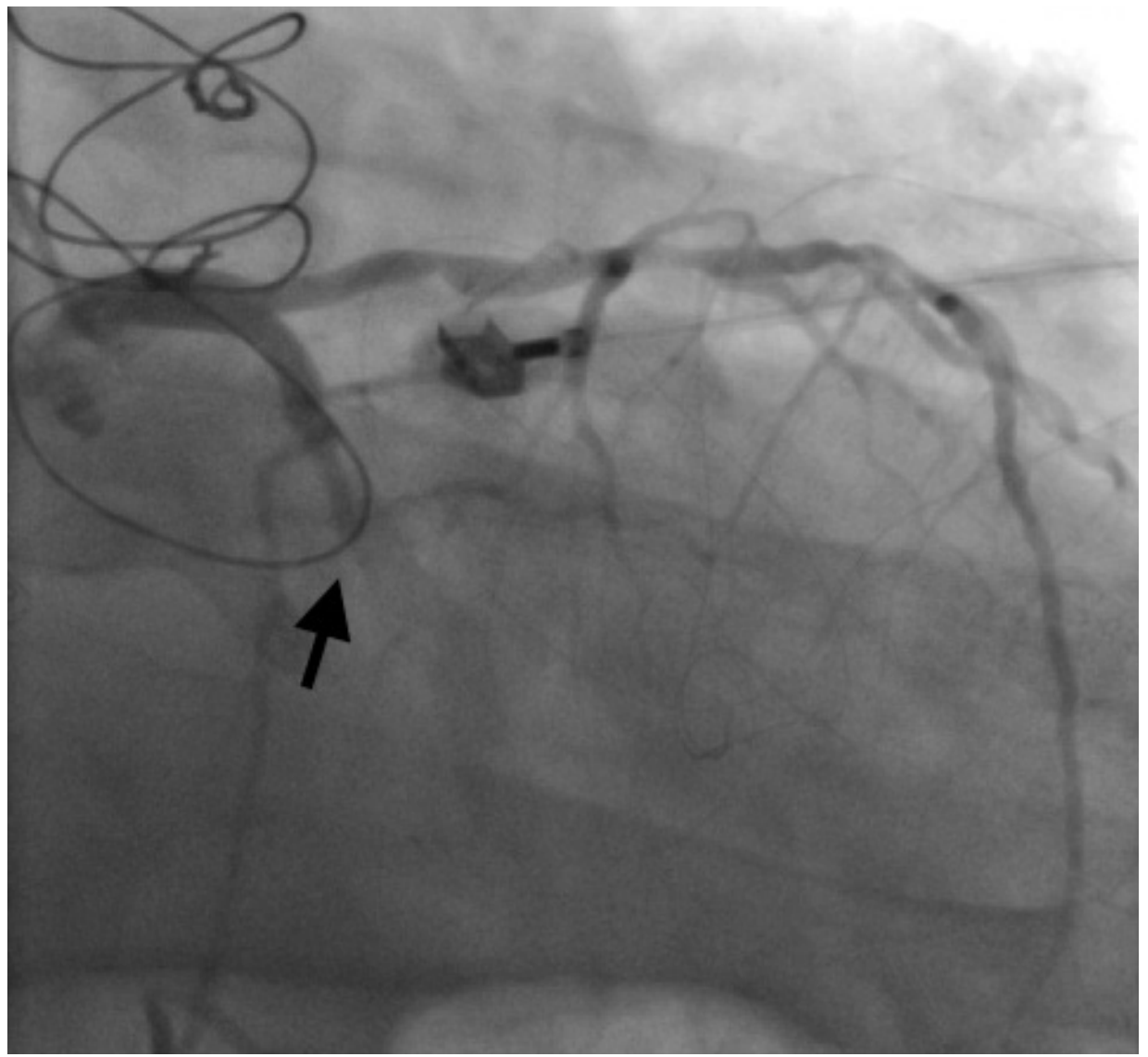

Fig 3. Coronary angiography showing occluded left circumflex artery $(\mathrm{Cx})$ and significantly narrowed left anterior descending artery (LAD)

Ryc. 3 Angiografia tętnic wieńcowych przedstawiająca zamkniętą tętnicę okalającą (Cx) i istotnie zwężoną gałąź międzykomorową przednią (LAD). 
therapy of pulmonary edema and myocardial infarction was applied (i.v. nitroglycerine and i.v. furosemide, a loading dose of clopidogrel). Dexamethasone was also administered intravenously. Due to the suspicion of acute myocardial ischemia, urgent coronary angiography showed occluded circumflex artery $(\mathrm{Cx})$ and significantly narrowed left anterior descending artery (LAD).

Percutaneous coronary angioplasty (PTCA) of the left circumflex artery was performed with implantation of two drug-eluting stents. Due to elevated inflammatory parameters, broad- spectrum empiric antibiotic treatment was started (meropenem, teicoplanin and antifungal caspofungin). Blood cultures were collected and cytomegalovirus PCR testing was performed. However, no causative pathogen was found.

Inflammatory parameters gradually decreased (CRP 27mg/l, procalcitonin $0.5 \mathrm{ng} / \mathrm{ml}$ ). However, hemodiafiltration was started due to progressive renal failure and following contrast administration. During renal replacement therapy, one week after the first PTCA, another stage of myocardial revascularization was performed (PTCA of LAD with drug-eluting stent implantation). After PTCA, cardiorespiratory decompensation occurred and urgent intubation was done. The patient presented with ongoing cardiorespiratory failure. After the next 10 days, an increase in inflammatory parameters was observed. The follow-up blood cultures confirmed Klebsiella pneumoniae and methicillin-resistant coagulasenegative Staphylococcus hemolyticus. Antibiotic therapy was reintroduced. Chest-CT showed the areas of ground-glass opacity initially suggesting pulmonary edema.

After three weeks of ventilator therapy and a gradual normalization of inflammatory parameters, antibiotic treatment was discontinued and the patient was extubated. The follow-up echocardiography showed slight improvement of the left ventricular contractile function and reduction of mitral regurgitation compared to the baseline. The patient was still on continuous renal replacement therapy.

In the following days, respiratory failure gradually relapsed, and noninvasive ventilation with continuous positive airway pressure (CPAP) mask was started. Due to further deterioration in gas exchange parameters, the patient was reintubated and mechanically ventilated. Asystole was reported and the patient died. Postmortem examination confirmed infarction of the lateral and inferior walls of the left ventricle and focal and subpleural lung fibrosis.

\section{Case three}

An 83-year-old male patient (7.5 years following heart transplantation) presented with fever, shortness of nasycająca dawka klopidokrelu). Podawano również dożylnie deksametazon. Z powodu podejrzenia ostrego niedokrwienia mięśnia sercowego wykonano pilną koronarografię; badanie uwidoczniło zamkniętą tętnicę okalającą $(\mathrm{Cx})$ oraz istotnie zwężoną gałąź międzykomorową przednią (LAD).

W trybie pilnym wykonano angioplastykę tętnicy okalającej z implantacją dwóch stentów uwalniających lek. Z powodu podwyższonych parametrów zapalnych włączono szerokospektralną antybiotykoterapię i leczenie przeciwgrzybicze (meropeniem, teikoplanina, kaspofungina). Pobrano posiewy krwi oraz wykonano badanie PCR w kierunku obecności wirusa cytomegalii. Nie wykryto jednak żadnego patogenu.

Parametry zapalne stopniowo obniżały się (CRP $27 \mathrm{mg} / \mathrm{l}$, prokalcytonina $0.5 \mathrm{ng} / \mathrm{ml})$. Jednak, najpewniej wskutek zastosowania środka kontrastowego obserwowano postępującą niewydolność nerek, która ostatecznie wymagała hemodiafiltracji. Podczas leczenia nerkozastępczego, tydzień po pierwszej angiolplastyce wykonano kolejny etap rewaskularyzacji (angioplastyka LAD z implantacją stentu uwalniającego lek). Po angioplastyce stan chorego pogorszył się i doszło do wystąpienia ostrej niewydolności krążeniowo-oddechowej wymagającej pilnej intubacji. U chorego utrzymywała się niewydolność krążeniowo-oddechowa. Po kolejnych 10 dniach, zaobserwowano wzrost parametrów zapalnych. Kolejne posiewy krwi potwierdziły wzrost Klebsiella pneumoniae i metycylinoopornego koagulazoujemnego gronkowca hemolizującego (methicillin-resistant coagulase-negative Staphylococcus hemolyticus). Ponownie wdrożono antybiotykoterapię. Wykonana tomografia komputerowa klatki piersiowej wykazała tzw. obszary mlecznej szyby.

Po trzech tygodniach respiratoroterapii i stopniowej normalizacji parametrów zapalnych zakończono antybiotykoterapię, a parametry wymiany gazowej pozwoliły na estubację chorego.

Kontrolna echokardiografia wykazała niewielką poprawę funkcji skurczowej lewej komory i redukcję niedomykalności zastawki mitralnej w porównaniu do badania wstępnego. Chory wymagał jednak w dalszym ciągu terapii nerkozastępczej.

W kolejnych dniach ponownie nawróciła niewydolność oddechowa, rozpoczęto wentylację nieinwazyjną przy użyciu maski CPAP. Z powodu dalszego pogorszenia parametrów wymiany gazowej chory wymagał ponownej intubacji i respiratoroterapii. W dalszym przebiegu klinicznym u chorego wystąpiła niereagująca na leczenie asystolia, chory zmarł. W badaniu sekcyjnym potwierdzono zawał ściany dolnej i bocznej oraz ogniskowe podopłucnowe włóknienie.

\section{Przypadek trzeci}


breath and cough. He treated himself with amoxicillin and clavulanic acid for 7 days with poor improvement. The patient had also a number of comorbidities including hypertension, diabetes, cardiac allograft vasculopathy, chronic kidney disease and chronic low lymphocyte count. He was also on immunosuppressive therapy consisting of mycophenolate mofetil $(500 \mathrm{mg}$ twice daily) in addition with a calcineurin inhibitor cyclosporine A (50mg twice daily). Attendant therapy comprised a calcium channel blocker (amlodipine $10 \mathrm{mg}$ ), angiotensin II receptor blockers (ARB, losartan $25 \mathrm{mg}$ ) and a statin (atorvastatin $10 \mathrm{mg}$ ). After 10 days from symptom onset, he was admitted to the community hospital with shortness of breath, and fever. The patient was COVID-19 positive by RT-PCR of nasopharyngeal swab specimens. Due to deterioration of clinical status, he required nasal oxygen supplementation. However, the patient died two days after admission to hospital due to septic shock

\section{Case four}

A 48-year-old woman (teacher by profession) with hypertension (5.5 years after heart transplant) presented with the symptoms of cough, fever and fatigue. She had laboratory- confirmed SARS-CoV-2 infection outside the hospital settings. She was on dual immunosuppression with extended-release tacrolimus (6mg; once daily) and mycophenolate mofetil (750mg; twice daily) which was suspended during the infection. Concomitant drugs included aspirin (75mg), a statin (rosuvastatin 20mg) and an angiotensin converting enzyme inhibitor (enalapril 5mg twice daily). She had an asymptomatic non-severe course of the infection within the following 14 days.

\section{Case five}

A 45-year-old male patient with no symptoms of infection was admitted for coronary angiography to monitor progression of graft vasculopathy. A nasopharyngeal swab was routinely collected to exclude SARS-CoV-2 infection. The test result was positive. Pre-laboratory errors were excluded because the result was also confirmed the following day (positive result of another specimen). The patient presented with no signs or symptoms of the COVID-19 infection. The family history was negative for SARS-CoV-2 infection. The clinical parameters were within the normal range (CRP $0.88 \mathrm{mg} / \mathrm{dl}$, creatinine $76 \mathrm{umol} / \mathrm{l}$, creatine kinase $81 \mathrm{U} / \mathrm{l}$ ) and peripheral blood count results were as follows: WBC $7.74 \mathrm{x} 10^{3} / \mu 1$, neutrophils $7.74 \times 10^{3} / \mu 1$, lymphocytes $1.46 \times 10^{3} / \mu 1$ HCT $41.9 \%$, PLT $198 \times 10^{3} / \mu 1$, HGB $9.1 \mathrm{mmol} / 1$. The patient was still on immunosuppression (extended-release tacrolimus and mycophenolate mofetil). The patient presented only with impaired glucose tolerance and hypercholesterolemia.
U 83-letniego mężczyzny (7,5 roku po przeszczepieniu serca) wystąpiła gorączka, kaszel i duszność. Wdrożono antybiotykoterapię amoksycyliną i kwasem klawulanowym przez 7 dni z niewielką poprawą. Pacjent był obciążony licznymi chorobami współistniejącymi takimi jak cukrzyca, nadciśnienie tętnicze waskulopatia serca przeszczepionego, przewlekła choroba nerek, przewlekła limfopenia. Pacjent otrzymywał leczenie immunosupresyjne złożone $\mathrm{z}$ mykofenolanu mofetylu (500mg dwa razy dziennie) jako dodatek do inhibitora kalcyneuryny- cyklosporyny A (50mg dwa razy dziennie). Terapia towarzysząca obejmowała bloker kanału wapniowwego (amlodypina 10mg), blokery receptora angiotensyny II (losartan $25 \mathrm{mg}$ ) oraz statynę (atorwastatyna $10 \mathrm{mg}$ ). Po 10 dniach od początku objawów pacjent został przyjęty do szpitala rejonowego z powodu nasilenia duszności oraz gorączki. U chorego potwierdzono COVID-19 na podstawie dodatniego wyniku RT -PCR wymazu z nosa i gardła. Z powodu dalszego pogorszenia niewydolności oddechowej pacjent wymagał początkowo tlenoterapii biernej. W dwa dni po przyjęciu do szpitala stan chorego gwałtownie się pogorszył i chory zmarł w objawach wstrząsu septycznego.

\section{Przypadek czwarty}

48-letnia kobieta, 5,5 roku po transplantacji serca, z zawodu nauczycielka obciążona nadciśnieniem tętniczym, zaczęła uskarżać się na kaszel, gorączkę, towarzyszące zmęczenie. U chorej potwierdzono w warunkach ambulatoryjnych obecność SARS-CoV-2. Pacjentka otrzymywała wyjściowo leczenie immunosupresyjne złożone $\mathrm{z}$ takrolimusu $\mathrm{w}$ formie o przedłużonym uwalnianiu (6mg, 1 raz dziennie) i mykofenolanu mofetylu (750 mg dwa razy dziennie), który został czasowo wstrzymany podczas infekcji. Leczenie towarzyszące obejmowało aspirynę $(75 \mathrm{mg}$ ), statynę (rosuwastatyna $20 \mathrm{mg}$ ) oraz inhibitor konwertazy angiotensyny (enalapril dwa razy dziennie). Łagodne objawy infekcyjne ustąpiły u chorej po 14 dniach.

\section{Przypadek piąty}

45-letni mężczyzna bez objawów infekcyjnych został planowo przyjęty celem wykonania protokolarnej koronarografii (dla wykluczenia waskulopatii graftu). $\mathrm{Z}$ dodatkowych obciążeń u chorego występowały jedynie nieprawidłowa tolerancja glukozy i hypercholesterolemia. Rutynowo pobrano wymaz RT-PCR w kierunku infekcji SARS-CoV-2, który dał wynik dodatni. Błąd przedlaboratoryjny wykluczono wykonując kolejny test. U chorego nie występowały żadne podmiotowe lub przedmiotowe objawy infekcji. Wywiad rodzinny w kierunku infekcji SARS-CoV-2 był ujemny. Parametry laboratoryjne pozostawały w zakresie prawidłowym (CRP $0.88 \mathrm{mg} / \mathrm{dl}$, kreatynina $76 \mu \mathrm{mol} / \mathrm{l}$, CPK $81 \mathrm{U} / 1$, morfologia krwi obwodowej również nie wykazywała 
Mycophenolate mofetil and atorvastatin were discontinued due to prophylactic reasons. One day after confirmation of SARS-CoV-2 infection the patient's son presented with myalgia, fever and cough. Twenty days after the confirmation of the virus, the patient was still SARS-CoV-2 positive, asymptomatic and remained under hospital supervision.

\section{DISCUSSION}

In the general population, patients with multimorbidity present with a severe course of the COVID-19 infection connected with acute respiratory failure. Immunosuppressive treatment may be associated with a worse course of the disease, high morbidity and mortality of the affected patients. However, of 552 patients after heart transplant who were under the supervision of the transplant outpatient clinic, only five COVID-19 infections were reported. The percentage of infections may have been significantly higher. However, it would have indicated only a mild course of the disease in this group of patients. A small number of symptomatic COVID-19 cases in patients after heart transplantation was also observed in the Chinese population (5).

Of note, despite multiple comorbidities, the above patients after transplantation presented with symptoms that were atypical of the clinical course in the general population. In three patients, signs and symptoms of severe pneumonia with desaturation typical of other patients with this disease were not observed. In the case of one male patient, intubation was performed, which was a result of cardiorespiratory failure. The patient presented with circulatory failure due to acute coronary syndrome, resulting probably from inflammatory activation in the course of COVID-19. These cardiovascular complications were also found in patients without prior solid organ transplantation (8). Exacerbation of chronic renal disease was observed in the male patient, which is a common phenomenon in organ recipients in the course of COVID-19 (9).

The signs and symptoms from the gastrointestinal tract were predominant in one of the female patients. Except for one patient admitted to the community hospital, mycophenolate mofetil was discontinued in all patients (temporary discontinuation in three patients and permanent discontinuation in one patient due to drug intolerance). Medications recommended for COVID-19 patients as part of clinical trials were not administered due to their inaccessibility and the concern of drug interactions with immunosuppression and potential toxicity.

One patient was an asymptomatic carrier of SARS$\mathrm{CoV}-2$. Due to the rapid progression of the disease in some cases, the patient underwent hospitalization.

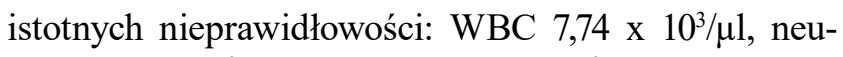
trofile $7,74 \times 10^{3} / \mu 1$, limfocyty $1,46 \times 10^{3} / \mu 1$ HCT $41,9 \%$, PLT $198 \times 10^{3} / \mu 1$, HGB 9,1mmol/1.

Pacjent otrzymywał immunosupresję złożoną z takrolimusu o przedłużonym uwalnianiu oraz mykofenolanu mofetylu, który czasowo wstrzymano $\mathrm{z}$ obawy przed pogorszeniem przebiegu klinicznego. Dzień po potwierdzeniu infekcji u syna chorego wystąpiły bóle mięśniowe, gorączka i kaszel. Dwadzieścia dni po pierwszym potwierdzeniu wirusa chory nadal posiadał dodatni wynik RT-PCR i pozostawał pod nadzorem szpitalnym.

\section{DYSKUSJA}

W populacji ogólnej osoby obciążone wielochorobowością prezentują cięższy przebieg kliniczny COVID-19 połączony z ostrą niewydolnością oddechową. Leczenie immunosupresyjne może być związane z gorszym przebiegiem klinicznym choroby, większą zachorowalnością i śmiertelnością. Jednak, spośród 552 chorych po ortotopowym przeszczepieniu serca, którzy pozostawali pod opieką poradni transplantacyjnej jedynie u pięciu stwierdzono infekcję SARS-CoV-2. Nie wykluczamy, że odsetek zainfekowanych pacjentów mógł być znacznie wyższy, co mogłoby jedynie wskazywać na łagodny przebieg kliniczny u tych chorych. Niski odsetek zainfekowanych chorych był również obserwowany w populacji chińskiej (5).

Co warte uwagi, mimo licznych chorób współistniejących, wyżej przedstawieni pacjenci prezentowali mało typowe objawy kliniczne. U trzech chorych nie obserwowano tak typowego dla jednostki klinicznej ciężkiego zapalenia płuc z desaturacją. U jednego chorego zaszła konieczność intubacji wskutek niewydolności krążeniowo-oddechowej. Chory ten prezentował objawy niewydolności krążenia wskutek ostrego zespołu wieńcowego będącego prawdopodobnie skutkiem aktywacji zapalnej wskutek COVID-19. Tego typu powikłania sercowo-naczyniowe były także obserwowane u chorych bez wcześniejszego przeszczepienia narządowego (8). Zaostrzenie przewlekłej choroby nerek także obserwowane u tego chorego jest relatywnie częstym zjawiskiem obserwowanym u chorych po przeszczepieniach narządowych w przebiegu COVID-19 (9).

$\mathrm{U}$ jednej z chorych dominowały objawy ze strony przewodu pokarmowego. Za wyjątkiem jednego przypadku, mykofenolan mofetylu przerwano u wszystkich otrzymujących go chorych (czasowo wstrzymano lek $\mathrm{u}$ trzech chorych, u jednego lek odstawiono wcześniej z powodu nietolerancji).

Leki stosowane w COVID-19 jako część badań klinicznych nie były podawane z powodu obaw przed ich toksycznością i interakcjami. 
Tacrolimus, which is an immunosuppressive agent, may have a beneficial effect on the third phase of the COVID-19 infection (6) in which inflammatory reactions play a crucial role and are decisive factors in terms of mortality of the affected patients.

\section{CONCLUSION}

The number of patients affected by COVID-19 in the Polish heart transplant population was relatively small. Interestingly, only 5 of 552 patients were confirmed with SARS-CoV-2 infection. Three patients with SARS-CoV-2 infection after OHT presented with a non-characteristic course of the infection. In a case of one woman, symptoms from the gastrointestinal tract and a low-grade fever were predominant. Inflammatory pulmonary changes were small and were found in the follow-up chest CT. In one man, graft vasculopathy and exacerbation of chronic renal failure were predominant. One male patient after a period of respiratory infection of moderate severity developed the signs and symptoms of septic shock. Immunosuppressive agents may have a beneficial role in the third phase of COVID-19 infection. However, patients who underwent heart transplantation seem to be particularly susceptible due to high rates of comorbidities.

\section{REFERENCES}

1. Latif F, Farr MA, Clerkin KJ. Characteristics and Outcomes of Recipients of Heart Transplant With Coronavirus Disease. JAMA Cardiology doi:10.1001/jamacardio.2020.2159

2. Pereira MR, Mohamed S, Husain S. et al. COVID-19 in Solid Organ Transplant Recipients: Initial Report form the US Epicenter, doi: 10.1111/AJT.15941

3. Aslam S, Mehra MR. COVID-19: Yet another coronavirus challenge in transplantation. ISHLT. doi: Https://doi.org/10.1016/j.healun.2020.03.007

4. Akalin E., Azzi Y., Bartash R. et al. NEJM. Doi: 10.1056/NEJMc20111117

5. Ren Z, Hu R., Wang Z. et al. Epidemiological and clinical characteristics of heart transplant recipient during the 2019 coronavirus outbreak in Wuhan, China: A descriptive survey report. ISHLT. doi: https://doi.org/10.1016/j.healun.2020.03.008

6. Siddiqi HK, Mehra MR. COVID-19 illness in native and immunosuppressed States: A clinicaltherapeutic staging proposal. ISHLT. doi: Https:// doi.org/10.1016/j.healun.2020.03.012

7. Aslam S. et al. Guidance for Cardiothoracic Transplant and Ventricular Assist Device Centers regarding the SARS Co-V-2 pandemic.
U jednego chorego stwierdzono bezobjawowe nosicielstwo SARS-CoV-2. Z powodu obaw przed szybką progresją do objawowej choroby pacjenta poddano hospitalizacji.

Przypuszczamy, że takrolimus, może mieć korzystny efekt w trzeciej fazie infekcji COVID-19 [6], w której nadmiernie wyrażone reakcje zapalne mogą odgrywać kluczową role u dotkniętego tą chorobą pacjenta.

\section{PODSUMOWANIE}

Liczba pacjentów dotkniętych COVID-19 w populacji pacjentów po transplantacji serca była względnie mała. Co ciekawe, jedynie u 5 spośród 552 w badanym okresie potwierdzono infekcję SARS-CoV-2. Chorzy po transplantacji serca prezentowali względnie niecharakterystyczny przebieg infekcji. W przypadku jednej kobiety dominowały objawy ze strony przewodu pokarmowego i stany podgoraczkowe. Zmiany zapalne w obrębie płuc były niewielkie i zaobserwowano je dopiero w kontrolnej tomografii. U jednego chorego dominowały waskulopatia graftu i zaostrzenie przewlekłej chotoby nerek. Jeden chory po okresie infekcji oddechowej o umiarkowanym nasileniu rozwinął objawy wstrząsu septycznego. Przypuszczamy, że niektóre leki immunosupresyjne, takie jak takrolimus mogą mieć korzystny wpływ w trzeciej fazie infekcji. Mimo tego wydaje się, że chorzy po przeszczepieniu serca są grupą wysoce podatną na ciężki przebieg choroby z powodu licznych chorób towarzyszących.

8. Dash D. Demystifying the conundrum of COVID-19 and cardiovascular system Iberoam J Med, Ahead of Print, 202

9. Yi SG, Rogers AW, Saharia AW. Early Experience With COVID-19 and Solid Organ Transplantation at a US High-Volume Transplant Center. Transplantation. 2020 Jun. Doi: D0.1097/ TP.0000000000003339

Received: 16.02.2021

Accepted for publication: 24.02.2021

Otrzymano: 16.02.2021 r.

Zaakceptowano do publikacji: 24.02.2021 r.

Address for correspondence: Adres do korespondencji:

Agnieszka Kuczaj, MD,PhD

Medical University of Silesia, Poland

Department of Cardiac, Vascular and Endovascular Surgery and Transplantology

Faculty of Medical Sciences in Zabrze

41-800 Zabrze, M.C.Skłodowskiej St. 9

Tel.323733 835 